DIW BERLIN

Discussion Papers

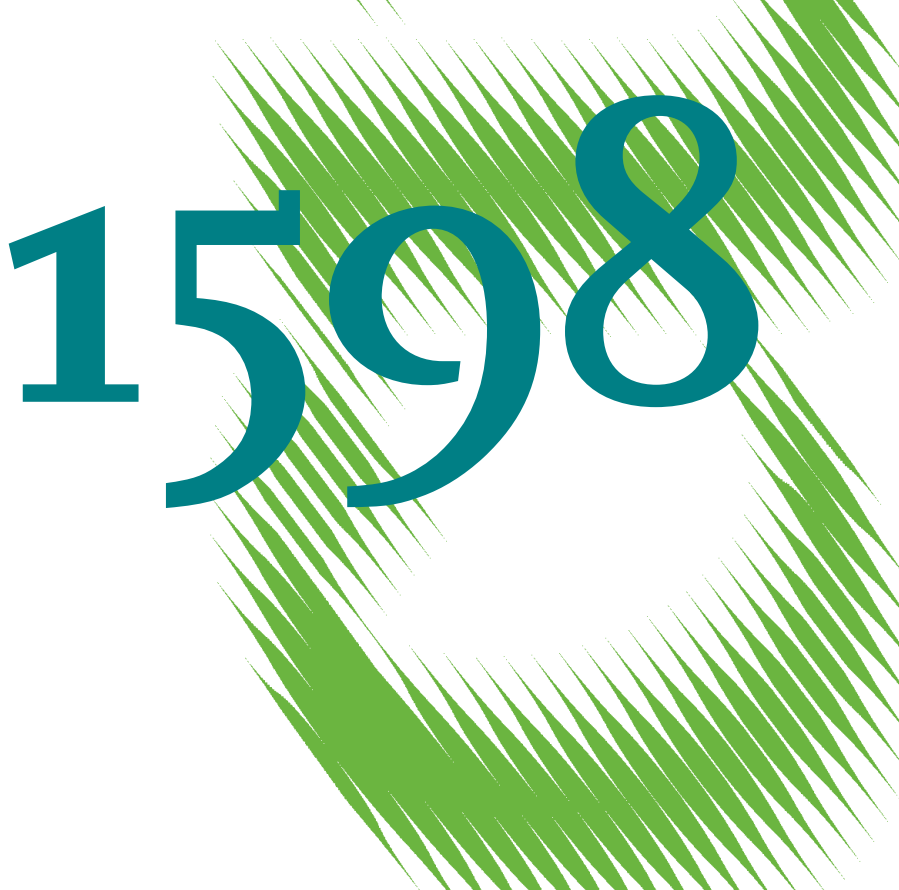

The End of Cheap Labour:

Are Foreign Investors Leaving

China? 
Opinions expressed in this paper are those of the author(s) and do not necessarily reflect views of the institute.

IMPRESSUM

(C) DIW Berlin, 2016

DIW Berlin

German Institute for Economic Research

Mohrenstr. 58

10117 Berlin

Tel. +49 (30) $89789-0$

Fax +49 (30) $89789-200$

http://www.diw.de

ISSN electronic edition 1619-4535

Papers can be downloaded free of charge from the DIW Berlin website:

http://www.diw.de/discussionpapers

Discussion Papers of DIW Berlin are indexed in RePEc and SSRN:

http://ideas.repec.org/s/diw/diwwpp.html

http://www.ssrn.com/link/DIW-Berlin-German-Inst-Econ-Res.html 


\title{
The End of Cheap Labour: Are Foreign Investors Leaving China?
}

\author{
Julian Donaubauer and Christian Dreger ${ }^{1}$
}

This version: July 2016

\begin{abstract}
China's government is promoting the shift towards a consumption-based economy since a few years. The explicit goal to significantly raise the percentage of wages in the national household income is integral part of the 12th Five-Year Plan (2011-15). The changes in the economic strategy are likely to affect the attractiveness of the country to foreign investors. In this paper, we raise the hypothesis that soaring wages negatively affect FDI inflows to China and alter the distribution of FDI over Chinese provinces. In addition, low-wage countries in the geographical surrounding might benefit from the changed direction of FDI inflows. By performing panel models with spatial effects for both Chinese provinces and developing ASEAN countries, regional dependencies are explicitly addressed. We provide strong and robust evidence that the wage increases change the distribution of FDI within China. In addition, we show that the changes in China's economic strategy improve the chances of its low-income neighbours to attract FDI.
\end{abstract}

Keywords: Foreign direct investment, Chinese economic transformation, spatial correlation JEL classification: F15, F21, F63, E22

\footnotetext{
${ }^{1}$ Donaubauer (corresponding author): Helmut-Schmidt University Hamburg, julian.donaubauer@hsu-hh.de; Dreger: German Institute for Economic Research (DIW Berlin), cdreger@diw.de. The paper has been written during a research stay of the first author at the DIW Berlin.
} 



\section{Introduction}

Due to China's rapid economic ascendance and its increasing integration into the world economy the country has become a leading destination for FDI. According to the UNCTAD FDI database, China has been the world's largest recipient of foreign investment in 2014.

During the early stages of China's economic development, a major aspect of the government's strategy was to attract export-oriented manufacturing FDI. In this context, China's huge market size, improving infrastructure, and relatively cheap labour costs have been the main pull factors for foreign investors. However, with the development of the economy and the emergence of a considerable middle class in recent years, China's government is increasingly stimulating the shift towards a consumption-based economy. In fact, the explicit goal to significantly raise the percentage of wages in the national household income is part of the country's 12th Five-Year Plan (2011-15). In 2013, average monthly wages in China amounted to about 600 USD. According to the ILO, this implies that Chinese wages are currently three times as high as in countries like Indonesia or Vietnam. While other costs for foreign investors (like increased environmental regulations and land prices) are also soaring, labour is the biggest factor.

These changes in the economic conditions are likely to affect China's attractiveness to foreign investors. Specifically, rising labour costs might undermine the country's competitiveness in labour intensive sectors (e.g. garments, shoes, or toy manufacturing) and prompt many low-cost manufacturers to shift labour intensive production to other locations in emerging Asia such as Cambodia, Indonesia, Thailand, or Vietnam, where labour costs are much lower. In contrast, the government strategy to promote FDI in high-tech sectors is not affected by the increase in wages, as the proportion of labour costs in the production of technological intensive goods is not very large. Hence, rising wages are expected to change the pattern of FDI inflows, and can also affect the distribution of FDI across regions or countries.

Despite the considerable amount of literature on the effects of China's inward FDI on other countries' attractiveness to foreign investors, the literature suffers from several limitations. First, not 
much attention is paid to the evolution of FDI determinants in China and their subsequent consequences for the local distribution of FDI flows. Second, regional dependencies and spillovers have been ignored. Their exclusion might lead to an omitted variable bias and can blur the regression results. Cross-sectional correlation might arise from common infrastructure or regional competition, among others. If these effects are neglected, policy recommendations may be invalid.

To overcome these deficits we estimate panel models incorporating spatial effects at the level of Chinese provinces and ASEAN economies. Regional dependencies are explicitly embedded in these settings. We find strong and robust evidence that increasing wages change the distribution of FDI within China. In addition, the changes in China's economic policy also increase the chances of lowincome neighbours to attract foreign investment.

The rest of the paper is structured as follows. In Section 2, we review the potential determinants of FDI, where special emphasis is given to the role of labour costs. The methodology and measurement issues are discussed in Section 3. Section 4 holds the results for Chinese provinces and ASEAN economies. Finally, Section 5 concludes with policy recommendations.

\section{Labour costs and FDI inflows}

From the variety of determinants potentially affecting FDI, the market size effect seems to be the most robust, i.e. larger countries receive higher FDI (Chakrabarti 2001 or Blonigen 2005). Despite that, lower labour costs can attract investments seeking for efficiency. Production could be realized at lower costs, i.e. the effect of labour costs on FDI should be negative. However, wages also reflect labour quality and productivity. If foreign investors demand higher skills, the overall effect of wages on FDI might be positive. Since the former effect might dominate for a low wage country, most of the literature on the determinants of FDI inflows to China has found negative responses of FDI to the wage level (see, e.g. Cheng and Kwan 2000, Coughlin and Segev 2000, Sun et al. 2002, or Chen 2011). However, higher wages in China might not only reduce the country's attractiveness to foreign investors. They might also change the distribution of FDI in developing Asia. In other words, it can 
be expected that low-wage neighbouring economies (like Indonesia or Vietnam) might benefit from increased FDI inflows at the expense of China.

There are a number of empirical studies on the effects of China's inward FDI on other countries' FDI inflows. All studies are motivated by the assumption that a growing China might crowd out FDI from its neighbours or other regions (particularly Eastern Europe or Latin America). Contrary to what one might expect, most authors find complementarities rather than substitution effects on other Asian countries' FDI inflows (Chantasasawat et al. 2004, 2008, 2010; Zhou and Lall 2005; Eichengreen and Tong 2006a; Cravino et al. 2007; Liu et al. 2007; Wang et al. 2007; Plummer and Cheong 2009; Chen 2010; Resmini and Siedschlag 2013). The increased fragmentation of production chains can play a major role for this result. In contrast, Mercereau (2005) reports negative effects for Asian economies. Eichengreen and Tong (2006b) find negative effects for countries that compete with China for horizontal FDI and positive effects for those competing for vertical FDI. García-Herrero and Santabárbara (2007) focus on the emergence of China as a large recipient of FDI and its consequences for Latin American economies. While they do not find an effect for Latin America as a region, they report negative effects for individual countries in the most recent past.

\section{Econometric methodology and data issues}

There are several reasons why regional variables can be spatially autocorrelated: For example, it can be expected that political decisions in one region or country can be affected by corresponding decisions in neighbouring regions. Additionally, spatial autocorrelation can arise from common shocks that hit the spatial units in similar ways. If not appropriately modelled, these regional spillovers lead to correlations over the cross-section and can blur the regression results (see, e.g. Anselin 1988).

To capture the potential impact of regional dependencies, the FDI inflows are explained in a spatial Durbin framework: 


$$
F D I_{i t}=\alpha+\beta_{1} \text { wages }_{i t-1}+\beta_{2} X_{i t-1}+p W F D I_{i t}+\sum_{j=1}^{k} \beta_{j k} X_{j t-1}+\sum_{j=1}^{k} \gamma_{j} W X_{j t-1}+\varepsilon_{i t}
$$

The index $i$ refers to the cross section, and $t$ denotes time. FDI refers to FDI inflows in percent of GDP and taken in logs, ${ }^{2}$ the vector $X_{i t}$ represents a set of control variables, and $\varepsilon_{t i}$ is the error term with white noise properties. The control variables include factors that are common in the literature on the FDI determinants (see, e.g. Blonigen and Piger 2014) and that have been found to be relevant in the Chinese case (e.g. Sun et al. 2002, Chen 2011, or Yin et al. 2014). They are lagged one period to reduce potential endogeneity. The wage variable is of particular interest. It is measured by the log of the monthly real minimum wage, where nominal wages have been deflated by the regional CPI. The choice of minimum wages is due to the fact that the variable is available for all regional units in the analysis. Hence, higher minimum wages are seen as an indication for a general rise in wages. ${ }^{3}$ In other words, wage differentials within a region or country are assumed to be constant. Empirically, minimum wages and wage levels are closely connected (see, e.g. Ma and Li 2016).

To control for cross section correlation, the model includes spatial lags in the dependent and independent variables. Specifically, $W$ is a spatial or contiguity matrix with information on the regional pattern. The elements of the matrix are equal to 1 or 0 , depending on whether two regions share a common border or not. Direct and indirect effects of the explanatory variables can be distinguished. While direct effects correspond to the partial derivatives of the endogenous variable with respect to exogenous variables in the same spatial unit, indirect effects arise as a result of impacts on the endogenous variable passing through neighbourhood regions and back to the region itself. The total impact of a regressor is calculated as the sum of the direct and indirect components. Equation (1) is estimated for panels of 29 Chinese provinces and six ASEAN economies (Indonesia, Cambodia, Laos, Philippines, Thailand, and Vietnam). The selection of these countries is motivated

\footnotetext{
${ }^{2}$ Ideally, we would have used FDI instocks instead of inflows, as instocks are typically less volatile than FDI inflows on an annual basis. However, FDI instocks are not available at the level of Chinese provinces.

${ }^{3}$ Increasing wages in China are likely to differ in their impact on different types of FDI. Higher wages can be expected to affect mostly efficiency-seeking FDI (or vertical FDI, which is mainly driven by differences in international factor prices). Horizontal or market-seeking FDI, in contrast, should not be affected as its main objective is to gain access to foreign markets and to avoid transport costs. However, the existing FDI data for China do not allow a disaggregated analysis for diverging FDI motives.
} 
by data availability. Annual series refer to the $2005-2013$ period and are reported by the Chinese Statistical Yearbook and the World Development Indicators of the World Bank. See Tables A1 and A2 for the summary statistics.

\section{Controls in the panel of Chinese provinces}

In the analysis, the control variables include the logs of GDP and GDP per capita as well as GDP growth of the host province. These variables proxy for the effects of market size, the level of development and the business cycle, respectively. Since a well-developed and sufficient infrastructure is widely believed to improve the chances to attract foreign investors (see e.g. Donaubauer et al. 2016), the length of highways relative to the provincial area is considered. To capture the impact of a better educated workforce, the share of people with college or better in the overall population is chosen. Further controls include the relevance of the private sector and urban concentration. While the former is approximated by the share of employees in privately owned companies in overall regional employment, the latter is defined as the share of the population living in urban areas.

\section{Controls in the panel of ASEAN countries}

To capture the effect of wage increases in China on the regional distribution of FDI, the focus is on the ASEAN member states. Due to their geographical proximity, FDI to these countries might also improve the presence of investors in the Chinese market. The countries included are Indonesia, Cambodia, Laos, Philippines, Thailand, and Vietnam. Wages are defined in relative terms, i.e. they refer to the real minimum wage relative to Chinese minimum wages. Further controls include GDP, GDP growth, and GDP per capita and the share of the population living in urban areas. Moreover, the institutional framework conditions are embedded via investment freedom (obtained from the Heritage 
Foundation). The latter reflects the restrictions on investment in the host country, where higher values indicate less restrictions. ${ }^{4}$

\section{Results}

\subsection{FDI determinants within China}

Although Chinese provinces are relatively large territorial entities, spatial connections between provinces are a widespread phenomenon in the country (see, e.g. Dreger et al. 2016). To determine whether FDI, wages, and the other variables in our model have a geographical dimension, we conduct the Moran's I test on spatial autocorrelation (Anselin 1988). Positive values point to regional clustering and negative values to regional dispersion. Table A3 presents the Moran coefficients for all the variables in the model. The null hypothesis of no spatial autocorrelation can be rejected at the 0.01 level for wages, GDP per capita, infrastructure, the size of the private sector, and the share of the urban population. Results are less clear for the other variables. FDI, education, and GDP exhibit a weaker spatial autocorrelation pattern (though still significant at the 0.1 level for most years in the sample period). Regional spillovers appear to be much weaker for GDP growth and industry. Despite the differences in individual variables, we find strong evidence for the existence of regional clusters. Hence, we estimate the determinants of FDI to Chinese provinces in the framework of a spatial panel model. Columns (1)-(3) of Table 1 present the results of equation (1).

[Table 1 here]

The findings for the control variables are in line with the existing literature and largely as expected. At the level of Chinese provinces, especially urban concentration, the size of the private sector, GDP per capita, and the GDP growth rate seem to attract FDI, whereas other potential determinants like

\footnotetext{
${ }^{4}$ Due to the non-availability of data for the sample at hand for infrastructure, education, industry, and private sector we were not able to control for these variables. To reduce the risk of any bias resulting from omitted variables we capture the potential effect of these variables via the inclusion of the lagged dependent variable.
} 
the level of education or infrastructure are less relevant. In the present context, the most interesting finding is probably that higher wages appear to discourage foreign investors. This is consistent with the view that lower labour costs can attract investments seeking for efficiency (rather than reflecting higher skill levels). The coefficient on the direct effect of wages proves to be statistically significant at the five percent level. In terms of the quantitative impact, an increase of minimum wages by one percent decreases the FDI-to-GDP ratio in the same region by roughly 0.6 percentage points. When looking at indirect effects of higher wages, we find that higher wages in neighbouring provinces tend to have positive effects on FDI inflows to a particular province. The non-significance of the total wage impact reflects the opposing direct and indirect effects.

In the following, a variety of robustness tests are performed. For a start, we employ different measures for the dependent FDI variable. Instead of the preferred measure (FDI as percent of the host province's GDP), in Columns (4)-(6) of Table 1 we consider (logged) FDI in absolute terms and FDI in per capita terms (logged) in Columns (7)-(9). As can be seen, the evidence on the relevance of wages for foreign investors is qualitatively as before.

As a further robustness check, for all three alternative definitions of the FDI variable we additionally estimate an ordinary panel model with provincial and year fixed effects included. Although the model is likely misspecified due to the omission of spatial lags, it nonetheless provides a useful reference for comparison. Results are presented in Table 2. Even though the findings differ somewhat in terms of the statistical significance and the magnitude of the effects of the control variables, our major findings carry over: wages have a strong and negative effect on FDI within China.

[Table 2 here]

\subsection{Chinese wages and FDI to neighbouring countries}

In this sub-section, we first test for global autocorrelation in the sample of developing ASEAN economies and then replicate the estimations of equation (1) for the country sample. Table A4 shows 
the Moran coefficients for all the variables in the model. Although the ASEAN economies are often smaller than some Chinese provinces, regional spillovers do not seem to play a major role in the country sample. For all the control variables the evidence for spatial correlation is rather weak. We find, however, some evidence that FDI exhibits positive and significant spatial autocorrelation. As regional correlation cannot be excluded, we first present estimation results with spatial lags included (Table 3).

[Table 3 here]

With the exception of GDP growth, which is found to negatively influence FDI, the effects of the control variables are largely as expected, although only freedom to invest and urban population are statistically significant. Turning to the relative wage variable we find strong and significant negative effects: the lower wages are relative to China, the more FDI is attracted to countries in China's geographical neighbourhood. When taking the coefficient on the wage variable at face value, the quantitative impact of the total effect is considerable: if relative wages are one percent lower, the FDI-to-GDP ratio is increased by 0.5 percentage points on average. When modifying the dependent variable (as in sub-section 4.1) in Columns (4)-(6) and (7)-(9) of Table 3, this finding is corroborated. In Columns (10)-(12) of Table 3, we return to the FDI-to-GDP ratio as our preferred FDI measure and include the lagged dependent variable to reduce the risk of omitted variables. The real wage variable remains significant in the extended setting.

[Table 4 here]

As the evidence for the existence of regional dependencies in the country sample is fairly weak, we provide the results of ordinary panel estimations (with country and time fixed effects included) in 
Table 4. Irrespective of the definition of the FDI variable, we find strong evidence that soaring wages in China improve the chances of its low-income neighbours to attract FDI.

\section{Summary and conclusion}

The adjustment of the economic strategy towards a larger role of private consumption in China has led to a significant rise in wages in recent years. The cost increase changed the attractiveness of the country for foreign investors. While China is still attractive with respect to its huge market potential, the country lost competitiveness as a destination for FDI driven by low cost motives in the labour intensive industries. Countries in the geographical surrounding benefit from this development.

The empirical findings based on panel models with fixed effects and spatial spillovers for Chinese provinces and developing ASEAN economies are largely consistent with this view. We provide strong and robust evidence that the Chinese wage increases changed the distribution of FDI both within China and Eastern Asia, as it improves the chances of the low-income neighbour countries to attract FDI. China is expected to receive less FDI in this segment, with adverse effects on industrial growth and subsequent employment losses. This poses new challenges to successfully implement the next stages of the economic transformation process. 


\section{References}

Anselin, L. (1988). Spatial econometrics: methods and models. Dordrecht, Kluwer Academic Publishers.

Blonigen, B.A. and Piger, J. (2014). Determinants of foreign direct investment. Canadian Journal of Economics, 47(3), 775-812.

Chakrabarti, A. (2001). The determinants of foreign direct investment: Sensitivity analyses of cross-country regressions. Kyklos, 54(1), 89-114.

Chantasasawat, B., Fung, K. C., Izaka, H. and Siu, A. (2004). The giant sucking sound: Is China diverting foreign direct investments from other Asian economies? Asian Economic Papers, 3(3), 122-140.

Chantasasawat, B., Fung, K. C., Izaka, H. and Siu, A. (2008). Multinational enterprises in China, East Asia, Latin America and Eastern Europe. Moving out or moving in? Journal of Chinese Economic and Foreign Trade Studies, 1(2), 122-135.

Chantasasawat, B., Fung, K. C., Izaka, H. and Siu, A. (2010). FDI flows to Latin America, East and Southeast Asia, and China: Substitutes or complements? Review of Development Economics, 14(3), 533546.

Chen, C. (2011). Provincial characteristics and the FDI location decision within China. In: Chen, C. (ed.): Foreign direct investment in China: Location determinants, investor differences, and economic impacts. UK: Elgar Publishing Limited, 132-151.

Chen, C. (2010). Asian foreign direct investment and the 'China effect'. In: Garnaut, R., Golley, J. and Song, L. (eds.): China: The next 20 years of reform and development. Canberra / Beijing: ANU E Press, 221-240.

Cheng, L.K. and Kwan, Y.K. (2000). What are the determinants of the location of foreign direct investment? The Chinese experience. Journal of International Economics, 51, 379-400.

Coughlin, C.C. and Segev, E. (2000). Foreign direct investment in China: A spatial econometric study. World Economy, 23(1), 1-23.

Cravino, J., Lederman, D. and Olarreaga, M. (2007). Substitution between foreign capital in China, India, the rest of the world, and Latin America: Much ado about nothing? Policy Research Working Paper 4361. The World Bank.

Donaubauer, J., Meyer, B. and Nunnenkamp, P. (2016). Aid, Infrastructure, and FDI: Assessing the Transmission Channel with a New Index of Infrastructure. World Development, 78 (2), 230-245. 
Dreger, C., Kosfeld, R. and Zhang, Y. (2016). Determining minimum wages in China: Do economic factors dominate? DIW Berlin Discussion Paper 1547.

Eichengreen, B. and Tong, H. (2006a). How China is reorganizing the world economy. Asian Economic Policy Review, 1, 73-97.

Eichengreen, B. and Tong, H. (2006b). Is China's FDI coming at the expense of other countries? Journal of the Japanese and International Economies, 21(2), 153-172.

García-Herrero, A. and Santabárbara, D. (2007). Does China have an impact on foreign direct investment in Latin America? China Economic Review, 18, 266-286.

Liu, L., Chow, K. and Li, U. (2007). Has China crowded out foreign direct investment from its developing East Asian neighbours? China and World Economy, 15, 70-88.

Ma, X. and Li, S. (2016). The effects of minimum wage on wage distribution in urban China: Evidences from CHIPs data. China Institute for Income Distribution Working Paper 46.

Mercereau, B. (2005). FDI flows to Asia: Did the dragon crowd out the tigers? IMF Working Paper 189. IMF.

Plummer, M. G. and Cheong, D. (2009). FDI effects of ASEAN integration. Région et Développement, 29 (6), 50-67.

Resmini, L. and Siedschlag, I. (2013). Is foreign direct investment to China crowding out the foreign direct investment to other countries? China Economic Review, 25 (6), 1-16.

Sun, Q., Tong, W. and Yu, Q. (2002). Determinants of foreign direct investment across China. Journal of International Money and Finance, 21, 79-113.

Wang, C., Wei, Y. and Liu, X. (2007). Does china rival its neighbouring economies for inward FDI. Transnational Corporation, 16(3), 35-60.

Yin, F., Ye, M. and Xu, L. (2014). Location determinants of foreign direct investment in services: Evidence from Chinese provincial-level data. London School of Economics and Political Science, Asia Research Centre Working Paper 64.

Zhou, Y. and Lall, S. (2005). The impact of China's FDI surge on FDI in South-East Asia: Panel data analysis for 1986-2001. Transnational Corporation, 14(1), 41-65. 
Table 1 -Regression results for provinces (spatial Durbin model)

\begin{tabular}{|c|c|c|c|c|c|c|c|c|c|}
\hline \multirow[b]{4}{*}{ Variables } & (1) & $(2)$ & (3) & (4) & $(5)$ & $(6)$ & (7) & $(8)$ & (9) \\
\hline & \multicolumn{9}{|c|}{ Dependent variable } \\
\hline & \multicolumn{3}{|c|}{$(\mathrm{FDI} / \mathrm{GDP})(\log )$} & \multicolumn{3}{|c|}{ FDI $(\log )$} & \multicolumn{3}{|c|}{ FDI_pc $(\log )$} \\
\hline & Direct & Indirect & Total & Direct & Indirect & Total & Direct & Indirect & Total \\
\hline \multirow[t]{2}{*}{ Wages $(\log )$} & $-0.567 * *$ & $0.818^{*}$ & 0.251 & $-0.611 * *$ & $0.800^{*}$ & 0.190 & $-0.624 * *$ & $0.845^{*}$ & 0.221 \\
\hline & $(0.268)$ & $(0.454)$ & $(0.491)$ & $(0.265)$ & $(0.447)$ & $(0.483)$ & $(0.263)$ & $(0.442)$ & $(0.475)$ \\
\hline \multirow[t]{2}{*}{ GDP_pc (log) } & $1.741 * *$ & -2.001 & -0.260 & $1.876^{* *}$ & -2.200 & -0.324 & $2.679 * * *$ & -2.277 & 0.401 \\
\hline & $(0.791)$ & $(1.505)$ & $(1.572)$ & $(0.781)$ & $(1.481)$ & $(1.545)$ & $(0.778)$ & $(1.464)$ & $(1.520)$ \\
\hline \multirow[t]{2}{*}{ GDP (log) } & $-2.576 * * *$ & 1.249 & -1.328 & $-2.026^{* *}$ & 1.312 & -0.714 & $-2.847 * * *$ & 1.442 & -1.405 \\
\hline & $(0.828)$ & $(1.404)$ & $(1.496)$ & $(0.817)$ & $(1.384)$ & $(1.474)$ & $(0.814)$ & $(1.366)$ & $(1.449)$ \\
\hline \multirow[t]{2}{*}{ GDP growth } & $0.0404 * *$ & $-0.0655^{* *}$ & -0.0250 & $0.0476 * * *$ & $-0.0664 * *$ & -0.0188 & $0.0477 * * *$ & $-0.0673 * *$ & -0.0196 \\
\hline & $(0.0160)$ & $(0.0274)$ & $(0.0307)$ & $(0.0158)$ & $(0.0270)$ & $(0.0301)$ & $(0.0157)$ & $(0.0267)$ & $(0.0297)$ \\
\hline \multirow[t]{2}{*}{ Infrastructure } & 0.229 & 0.317 & 0.546 & 0.184 & 0.333 & 0.516 & 0.168 & 0.311 & 0.479 \\
\hline & $(0.187)$ & $(0.390)$ & $(0.367)$ & $(0.185)$ & $(0.385)$ & $(0.361)$ & $(0.185)$ & $(0.381)$ & $(0.355)$ \\
\hline \multirow[t]{2}{*}{ Education } & -1.392 & -0.0188 & -1.411 & -1.279 & 0.0700 & -1.209 & -1.451 & 0.00934 & -1.441 \\
\hline & $(1.803)$ & $(2.790)$ & $(2.876)$ & (1.779) & $(2.750)$ & $(2.834)$ & $(1.775)$ & $(2.721)$ & $(2.789)$ \\
\hline \multirow[t]{2}{*}{ Industry } & -0.00552 & -0.00267 & -0.00819 & -0.00425 & -0.00212 & -0.00637 & -0.00423 & -0.00191 & -0.00615 \\
\hline & $(0.0117)$ & $(0.0198)$ & $(0.0201)$ & $(0.0116)$ & $(0.0195)$ & $(0.0198)$ & $(0.0116)$ & $(0.0193)$ & $(0.0195)$ \\
\hline \multirow[t]{2}{*}{ Private sector } & $1.380^{*}$ & $4.184 * *$ & $5.564 * * *$ & $1.337 *$ & $3.997 * *$ & $5.334 * * *$ & $1.225^{*}$ & $3.899 * *$ & $5.124 * * *$ \\
\hline & $(0.728)$ & $(1.810)$ & $(1.883)$ & $(0.719)$ & $(1.783)$ & $(1.854)$ & $(0.716)$ & $(1.762)$ & $(1.825)$ \\
\hline \multirow[t]{2}{*}{ Pop_urban } & $0.0427 * * *$ & $0.0962 * * *$ & $0.139 * * *$ & $0.0411 * * *$ & $0.0931 * * *$ & $0.134 * * *$ & $0.0414 * * *$ & $0.0923 * * *$ & $0.134 * * *$ \\
\hline & $(0.0125)$ & $(0.0246)$ & $(0.0282)$ & $(0.0124)$ & $(0.0242)$ & $(0.0278)$ & $(0.0123)$ & $(0.0239)$ & $(0.0273)$ \\
\hline Observations & 261 & 261 & 261 & 261 & 261 & 261 & 261 & 261 & 261 \\
\hline R-squared & 0.002 & 0.002 & 0.002 & 0.071 & 0.071 & 0.071 & 0.012 & 0.012 & 0.012 \\
\hline Number of provinces & 29 & 29 & 29 & 29 & 29 & 29 & 29 & 29 & 29 \\
\hline
\end{tabular}


Table 2 -Regression results for provinces (panel fixed effects model)

\begin{tabular}{lccc}
\hline & $(1)$ & $(2)$ & $(3)$ \\
Variables & & Dependent variable & \\
\hline Wages $(\log )$ & (FDI/GDP) $(\log )$ & FDI $(\log )$ & $-0.744^{* *}$ \\
GDP_pc $(\log )$ & $(0.310)$ & $-0.731^{* *}$ & $(0.306)$ \\
& $1.582^{*}$ & $(0.306)$ & $2.592^{* * *}$ \\
GDP $(\log )$ & $(0.843)$ & $1.763 * *$ & $(0.830)$ \\
& $-2.359^{* * *}$ & $(0.832)$ & $-2.699^{* * *}$ \\
GDP growth & $(0.882)$ & $-1.849^{* *}$ & $(0.869)$ \\
& $0.0415^{* *}$ & $(0.870)$ & $0.0490^{* * *}$ \\
Infrastructure & $(0.0169)$ & $0.0493 * * *$ & $(0.0166)$ \\
& 0.259 & $(0.0166)$ & 0.201 \\
Education & $(0.218)$ & 0.217 & $(0.215)$ \\
& -1.319 & $(0.216)$ & -1.389 \\
Industry & $(2.345)$ & -1.209 & $(2.310)$ \\
& -0.00446 & $(2.314)$ & -0.00260 \\
Private sector & $(0.0119)$ & -0.00276 & $(0.0117)$ \\
& 0.642 & $(0.0117)$ & 0.570 \\
Pop_urban & $(0.917)$ & 0.653 & $(0.903)$ \\
& 0.0187 & $(0.905)$ & 0.0186 \\
Observations & $(0.0163)$ & 0.0181 & $(0.0160)$ \\
R-squared & 261 & $(0.0160)$ & 261 \\
Number of provinces & 0.190 & 261 & 0.475 \\
\hline Notes: Stan & 0.491 & 29 \\
\hline
\end{tabular}

Notes: Standard errors in parentheses. ${ }^{* * *} \mathrm{p}<0.01,{ }^{*} \mathrm{p}<0.05,{ }^{*} \mathrm{p}<0.1$. All equations include province and year fixed effects. All explanatory variables are lagged by one year. 
Table 3 -Regression results for ASEAN countries (spatial Durbin model)

\begin{tabular}{|c|c|c|c|c|c|c|c|c|c|c|c|c|}
\hline \multirow[b]{4}{*}{ Variables } & (1) & (2) & (3) & (4) & (5) & (6) & (7) & (8) & (9) & (10) & (11) & (12) \\
\hline & \multicolumn{12}{|c|}{ Dependent variable } \\
\hline & \multicolumn{3}{|c|}{ (FDI/GDP) (log) } & \multicolumn{3}{|c|}{ FDI $(\log )$} & \multicolumn{3}{|c|}{ FDI pc $(\log )$} & \multicolumn{3}{|c|}{ FDI/GDP (log) } \\
\hline & Direct & Indirect & Total & Direct & Indirect & Total & Direct & Indirect & Total & Direct & Indirect & Total \\
\hline Relative Wages (log) & $\begin{array}{c}-0.251^{* *} \\
(0.121)\end{array}$ & $\begin{array}{l}-0.248^{*} \\
(0.143)\end{array}$ & $\begin{array}{c}-0.500 * * * \\
(0.0982)\end{array}$ & $\begin{array}{c}-0.273^{* *} \\
(0.118)\end{array}$ & $\begin{array}{l}-0.0593 \\
(0.151)\end{array}$ & $\begin{array}{c}-0.332 * * * \\
(0.118)\end{array}$ & $\begin{array}{c}-0.273^{* *} \\
(0.118)\end{array}$ & $\begin{array}{l}-0.0602 \\
(0.151)\end{array}$ & $\begin{array}{c}-0.333^{* * *} \\
(0.117)\end{array}$ & $\begin{array}{c}-0.141 \\
(0.0892)\end{array}$ & $\begin{array}{l}-0.196 \\
(0.165)\end{array}$ & $\begin{array}{c}-0.336^{* * *} \\
(0.127)\end{array}$ \\
\hline GDP_pc (log) & $\begin{array}{c}2.482 \\
(4.315)\end{array}$ & $\begin{array}{l}-3.903 \\
(3.581)\end{array}$ & $\begin{array}{l}-1.420 \\
(4.200)\end{array}$ & $\begin{array}{l}-7.169 \\
(4.641)\end{array}$ & $\begin{array}{c}0.464 \\
(3.734)\end{array}$ & $\begin{array}{l}-6.704 \\
(5.027)\end{array}$ & $\begin{array}{l}-6.120 \\
(4.620)\end{array}$ & $\begin{array}{c}0.527 \\
(3.724)\end{array}$ & $\begin{array}{l}-5.594 \\
(4.990)\end{array}$ & $\begin{array}{l}-0.478 \\
(4.179)\end{array}$ & $\begin{array}{l}-0.588 \\
(3.053)\end{array}$ & $\begin{array}{l}-1.067 \\
(5.091)\end{array}$ \\
\hline GDP $(\log )$ & $\begin{array}{l}-1.104 \\
(3.764)\end{array}$ & $\begin{array}{c}2.819 \\
(3.123)\end{array}$ & $\begin{array}{c}1.715 \\
(4.191)\end{array}$ & $\begin{array}{l}8.019 * * \\
(4.091)\end{array}$ & $\begin{array}{l}-0.188 \\
(3.339)\end{array}$ & $\begin{array}{c}7.831 \\
(5.016)\end{array}$ & $\begin{array}{l}6.968^{*} \\
(4.072)\end{array}$ & $\begin{array}{l}-0.246 \\
(3.334)\end{array}$ & $\begin{array}{c}6.723 \\
(4.980)\end{array}$ & $\begin{array}{c}0.938 \\
(3.683)\end{array}$ & $\begin{array}{c}0.226 \\
(2.706)\end{array}$ & $\begin{array}{c}1.164 \\
(4.889)\end{array}$ \\
\hline GDP growth & $\begin{array}{c}-0.0139 * * \\
(0.00701)\end{array}$ & $\begin{array}{l}0.00441 \\
(0.0118)\end{array}$ & $\begin{array}{l}-0.00947 \\
(0.00961)\end{array}$ & $\begin{array}{l}-0.00767 \\
(0.00689)\end{array}$ & $\begin{array}{l}0.00237 \\
(0.0126)\end{array}$ & $\begin{array}{l}-0.00529 \\
(0.0117)\end{array}$ & $\begin{array}{l}-0.00760 \\
(0.00685)\end{array}$ & $\begin{array}{l}0.00248 \\
(0.0125)\end{array}$ & $\begin{array}{r}-0.00513 \\
(0.0116)\end{array}$ & $\begin{array}{l}-0.0108^{*} \\
(0.00566)\end{array}$ & $\begin{array}{l}-0.0110 \\
(0.0106)\end{array}$ & $\begin{array}{c}-0.0218^{* *} \\
(0.0105)\end{array}$ \\
\hline Investment freedom & $\begin{array}{c}0.00737 * * * \\
(0.00263)\end{array}$ & $\begin{array}{l}-0.00148 \\
(0.00617)\end{array}$ & $\begin{array}{c}0.00589 \\
(0.00549)\end{array}$ & $\begin{array}{c}0.00628 * * \\
(0.00253)\end{array}$ & $\begin{array}{c}0.00332 \\
(0.00675)\end{array}$ & $\begin{array}{c}0.00960 \\
(0.00665)\end{array}$ & $\begin{array}{c}0.00613 * * \\
(0.00253)\end{array}$ & $\begin{array}{c}0.00334 \\
(0.00671)\end{array}$ & $\begin{array}{c}0.00947 \\
(0.00659)\end{array}$ & $\begin{array}{c}0.00368 \\
(0.00240)\end{array}$ & $\begin{array}{l}0.0130^{* *} \\
(0.00554)\end{array}$ & $\begin{array}{c}0.0167 * * * \\
(0.00558)\end{array}$ \\
\hline Pop_urban & $\begin{array}{c}0.0397 * * \\
(0.0194)\end{array}$ & $\begin{array}{c}-0.00386 \\
(0.0237)\end{array}$ & $\begin{array}{c}0.0358 \\
(0.0220)\end{array}$ & $\begin{array}{c}0.0813^{* * *} * \\
(0.0214)\end{array}$ & $\begin{array}{c}0.0716^{* * *} \\
(0.0254)\end{array}$ & $\begin{array}{l}0.00965 \\
(0.0263)\end{array}$ & $\begin{array}{c}0.0812^{* * *} \\
(0.0213)\end{array}$ & $\begin{array}{c}0.0720^{* * *} \\
(0.0252)\end{array}$ & $\begin{array}{l}0.00924 \\
(0.0261)\end{array}$ & $\begin{array}{l}0.00826 \\
(0.0187)\end{array}$ & $\begin{array}{l}0.00777 \\
(0.0242)\end{array}$ & $\begin{array}{c}0.0160 \\
(0.0236)\end{array}$ \\
\hline Lagged dep. variable & & & & & & & & & & $\begin{array}{c}0.245^{* * * *} \\
(0.0898)\end{array}$ & $\begin{array}{c}-0.436^{* * *} \\
(0.122)\end{array}$ & $\begin{array}{l}-0.191^{* *} \\
(0.0951)\end{array}$ \\
\hline Observations & 54 & 54 & 54 & 54 & 54 & 54 & 54 & 54 & 54 & 54 & 54 & 54 \\
\hline R-squared & 0.663 & 0.663 & 0.663 & 0.900 & 0.900 & 0.900 & 0.216 & 0.216 & 0.216 & 0.097 & 0.097 & 0.097 \\
\hline Number of countries & 6 & 6 & 6 & 6 & 6 & 6 & 6 & 6 & 6 & 6 & 6 & 6 \\
\hline
\end{tabular}

Notes: Standard errors in parentheses. ${ }^{* * *} \mathrm{p}<0.01, * * \mathrm{p}<0.05,{ }^{*} \mathrm{p}<0.1$. All equations include country and year fixed effects (not reported). All explanatory variables are lagged by one year. 
Table 4 -Regression results for ASEAN countries (panel fixed effects model)

\begin{tabular}{|c|c|c|c|}
\hline & (1) & $(2)$ & (3) \\
\hline & & Dependent variable & \\
\hline & (FDI/GDP) (log) & FDI $(\log )$ & FDI_pc (log) \\
\hline \multicolumn{4}{|l|}{ Variables } \\
\hline \multirow[t]{2}{*}{ Relative Wages (log) } & $-0.381 * * *$ & $-0.388 * *$ & $-0.390 * *$ \\
\hline & $(0.108)$ & $(0.144)$ & $(0.143)$ \\
\hline \multirow[t]{2}{*}{ GDP_pc (log) } & -0.670 & $-6.138^{*}$ & -5.160 \\
\hline & $(2.526)$ & $(3.365)$ & $(3.357)$ \\
\hline \multirow[t]{2}{*}{ GDP $(\log )$} & 1.449 & $6.870^{* *}$ & $5.884^{* *}$ \\
\hline & $(2.147)$ & $(2.860)$ & $(2.853)$ \\
\hline \multirow[t]{2}{*}{ GDP growth } & -0.00416 & 0.00745 & 0.00748 \\
\hline & $(0.00806)$ & $(0.0107)$ & $(0.0107)$ \\
\hline \multirow[t]{2}{*}{ Investment freedom } & $0.00562 * *$ & 0.00237 & 0.00226 \\
\hline & $(0.00243)$ & $(0.00323)$ & $(0.00323)$ \\
\hline \multirow[t]{2}{*}{ Pop_urban } & $0.0574 * * *$ & $0.0916^{* * *}$ & $0.0918 * * *$ \\
\hline & $(0.0179)$ & $(0.0239)$ & $(0.0238)$ \\
\hline Observations & 54 & 54 & 54 \\
\hline R-squared & 0.739 & 0.951 & 0.943 \\
\hline Number of countries & 6 & 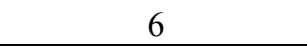 & 6 \\
\hline
\end{tabular}




\section{Appendix}

Table A1 - Summary statistics for Chinese provinces

\begin{tabular}{lccccc}
\hline Variable & Observations & Mean & Std. Dev. & Min & Max \\
\hline (FDI/GDP) (log) & 261 & 2.490 & 1.944 & 0.068 & 8.192 \\
Wages (log) & 261 & 6.156 & 0.309 & 5.449 & 7.035 \\
GDP_pc (log) & 261 & 9.915 & 0.544 & 8.525 & 11.215 \\
GDP (log) & 261 & 6.577 & 0.942 & 3.893 & 8.460 \\
GDP growth & 261 & 12.493 & 2.263 & 5.400 & 23.800 \\
Infrastructure & 261 & 0.739 & 0.417 & 0.041 & 1.601 \\
Education & 261 & 0.084 & 0.054 & 0.025 & 0.393 \\
Industry & 261 & 48.399 & 7.777 & 21.700 & 61.500 \\
Private sector & 261 & 0.444 & 0.150 & 0.154 & 0.805 \\
Pop_urban & 261 & 49.307 & 12.568 & 26.870 & 86.300 \\
\hline
\end{tabular}

Table A2 - Summary statistics for ASEAN countries

\begin{tabular}{lccccc}
\hline Variable & Observations & Mean & Std. Dev. & Min & Max \\
\hline (FDI/GDP) (log) & 54 & -10.457 & 0.509 & -11.385 & -9.693 \\
Relative Wages (log) & 54 & -0.491 & 0.752 & -2.087 & 0.796 \\
GDP_pc (log) & 54 & 7.015 & 0.591 & 6.158 & 8.136 \\
GDP (log) & 54 & 24.683 & 1.693 & 21.730 & 26.831 \\
GDP growth & 54 & 6.106 & 2.484 & -0.738 & 13.250 \\
Investment freedom & 54 & 35.000 & 10.989 & 15.000 & 60.000 \\
Pop_urban & 54 & 36.475 & 10.551 & 19.174 & 52.252 \\
\hline
\end{tabular}


Table A3 - Moran coefficient for the variables in the model (Chinese provinces sample)

\begin{tabular}{|c|c|c|c|c|c|}
\hline Year & (FDI/GDP) (log) & Wages (log) & GDP_pc (log) & GDP (log) & GDP growth \\
\hline 2005 & $0.370(0.001)$ & $0.436(0.000)$ & $0.423(0.000)$ & $0.139(0.078)$ & $-0.104(0.220)$ \\
\hline 2006 & $0.349(0.001)$ & $0.301(0.003)$ & $0.411(0.000)$ & $0.129(0.089)$ & $-0.031(0.483)$ \\
\hline 2007 & $0.308(0.003)$ & $0.265(0.007)$ & $0.407(0.000)$ & $0.134(0.083)$ & $-0.161(0.144)$ \\
\hline 2008 & $0.249(0.011)$ & $0.310(0.002)$ & $0.391(0.000)$ & $0.135(0.082)$ & $-0.086(0.343)$ \\
\hline 2009 & $0.144(0.065)$ & $0.314(0.002)$ & $0.389(0.000)$ & $0.142(0.073)$ & $-0.105(0.282)$ \\
\hline 2010 & $0.089(0.145)$ & $0.416(0.000)$ & $0.384(0.000)$ & $0.145(0.070)$ & $-0.210(0.080)$ \\
\hline 2011 & $0.026(0.302)$ & $0.260(0.007)$ & $0.376(0.000)$ & $0.143(0.072)$ & $0.044(0.259)$ \\
\hline 2012 & $0.070(0.182)$ & $0.427(0.000)$ & $0.366(0.001)$ & $0.147(0.067)$ & $0.174(0.047)$ \\
\hline 2013 & $0.076(0.169)$ & $0.371(0.000)$ & $0.348(0.001)$ & $0.147(0.067)$ & $0.172(0.048)$ \\
\hline Year & Infrastructure & Education & Industry & Private sector & Pop_urban \\
\hline 2005 & $0.603(0.000)$ & $0.328(0.000)$ & $-0.056(0.434)$ & $0.257(0.009)$ & $0.377(0.000)$ \\
\hline 2006 & $0.609(0.000)$ & $0.240(0.001)$ & $-0.068(0.396)$ & $0.305(0.003)$ & $0.376(0.000)$ \\
\hline 2007 & $0.603(0.000)$ & $0.233(0.001)$ & $-0.037(0.495)$ & $0.275(0.006)$ & $0.383(0.000)$ \\
\hline 2008 & $0.607(0.000)$ & $0.246(0.001)$ & $-0.031(0.484)$ & $0.294(0.004)$ & $0.392(0.000)$ \\
\hline 2009 & $0.610(0.000)$ & $0.287(0.000)$ & $0.008(0.352)$ & $0.302(0.003)$ & $0.410(0.000)$ \\
\hline 2010 & $0.600(0.000)$ & $0.277(0.000)$ & $0.028(0.284)$ & $0.342(0.001)$ & $0.364(0.000)$ \\
\hline 2011 & $0.602(0.000)$ & $0.172(0.013)$ & $0.050(0.223)$ & $0.398(0.000)$ & $0.351(0.001)$ \\
\hline 2012 & $0.619(0.000)$ & $0.192(0.010)$ & $0.028(0.288)$ & $0.445(0.000)$ & $0.340(0.001)$ \\
\hline 2013 & $0.626(0.000)$ & $0.221(0.003)$ & $0.009(0.345)$ & $0.473(0.000)$ & $0.342(0.001)$ \\
\hline
\end{tabular}


Table A4 - Moran coefficient for the variables in the model (ASEAN sample)

\begin{tabular}{|c|c|c|c|c|c|c|c|}
\hline Year & $(\mathrm{FDI} / \mathrm{GDP})(\log )$ & $\begin{array}{c}\text { Relative Wages } \\
(\log )\end{array}$ & GDP_pc (log) & GDP $(\log )$ & GDP growth & Investment freedom & Pop_urban \\
\hline 2005 & $0.148(0.111)$ & $-0.207(0.489)$ & $-0.311(0.331)$ & $-0.032(0.268)$ & $-0.209(0.480)$ & $-0.217(0.403)$ & $0.182(0.085)$ \\
\hline 2006 & $0.201(0.079)$ & $-0.193(0.490)$ & $-0.316(0.323)$ & $-0.032(0.268)$ & $-0.094(0.336)$ & $-0.217(0.403)$ & $0.150(0.103)$ \\
\hline 2007 & $0.182(0.078)$ & $-0.181(0.472)$ & $-0.318(0.319)$ & $-0.030(0.265)$ & $-0.284(0.330)$ & $-0.217(0.403)$ & $0.116(0.124)$ \\
\hline 2008 & $0.174(0.091)$ & $-0.202(0.497)$ & $-0.318(0.319)$ & $-0.025(0.259)$ & $-0.414(0.176)$ & $-0.217(0.403)$ & $0.080(0.150)$ \\
\hline 2009 & $0.093(0.136)$ & $-0.200(0.500)$ & $-0.318(0.320)$ & $-0.015(0.248)$ & $-0.273(0.397)$ & $-0.417(0.160)$ & $0.044(0.180)$ \\
\hline 2010 & $0.035(0.187)$ & $-0.175(0.465)$ & $-0.321(0.315)$ & $-0.016(0.249)$ & $-0.287(0.373)$ & $-0.294(0.341)$ & $0.007(0.215)$ \\
\hline 2011 & $0.062(0.152)$ & $-0.157(0.439)$ & $-0.320(0.318)$ & $-0.007(0.238)$ & $-0.377(0.224)$ & $-0.295(0.341)$ & $-0.029(0.254)$ \\
\hline 2012 & $0.065(0.144)$ & $-0.220(0.471)$ & $-0.320(0.317)$ & $-0.006(0.238)$ & $0.133(0.096)$ & $-0.295(0.341)$ & $-0.062(0.294)$ \\
\hline 2013 & $-0.008(0.221)$ & $-0.224(0.466)$ & $-0.315(0.324)$ & $0.002(0.229)$ & $-0.518(0.088)$ & $-0.380(0.234)$ & $-0.093(0.335)$ \\
\hline
\end{tabular}

Notes: $p$-values in parentheses. 